\title{
Gender (in)equality within the household and business start-up among mothers
}

\author{
Lucia Naldi • Massimo Baù • Helene Ahl • \\ Magdalena Markowska
}

\begin{abstract}
Using data on all businesses started by mothers of young children in Sweden between 2000 and 2014, we explore which factors are associated with entrepreneurship among mothers. We find that being unemployed or being an immigrant is positively associated with business start-up by mothers; however, our findings show that what matters more is the paternity leave taken by the mothers' partners. These findings suggest that in institutional contexts such as Sweden, gender inequality is not a persistent feature of most households and that women can make career choices
\end{abstract}

L. Naldi $\cdot$ M. Baù $\cdot$ M. Markowska

Centre for Family Enterprise and Ownership (CeFEO), Jönköping International Business School, PO Box 1026, SE-551

11 Jönköping, Sweden

M. Baù

e-mail: massimo.bau@ju.se

M. Markowska

e-mail: Magdalena.Markowska@ju.se

L. Naldi $(\bowtie)$

Centre for Entrepreneurship and Spatial Economics (CEnSE), Jönköping International Business School, PO Box 1026, SE-551 11 Jönköping, Sweden

e-mail: lucia.naldi@ju.se

H. Ahl

School of Education and Communication, The National Centre for Lifelong Learning (Encell), Jönköping University, PO Box 1026,

SE-551 11 Jönköping, Sweden

e-mail: helene.ahl@ju.se by negotiating with their partners who will make use of the parental benefits offered by the government.

Keywords Entrepreneurship - Gender inequality · Family supportive policies $\cdot$ Work-family balance

JEL classifications M13 $\cdot$ L26 $\cdot$ J24 J64

\section{Introduction}

While diverse individual-level factors can drive women into entrepreneurship, entrepreneurship scholars have recently begun to explore the role of macro-level institutional factors in shaping women's entrepreneurship (Brush et al. 2017; Estrin and Mickiewicz 2011; Giménez and Calabrò 2017). This research suggests that contexts characterized by institutional arrangements that support work-family balance - such as generous parental leave policies - are less conducive to entrepreneurship among women than are other contexts (Thébaud 2015). This phenomenon occurs for two interconnected reasons. First, in these contexts, mothers of young children are less likely to be pushed into entrepreneurship as a fallback strategy to accommodate work and childcare. Second, the benefits of arrangements such as paid parental leave are connected to wage employment and cannot be entirely realized by mothers starting their own businesses (Anxo and Ericson 2015).

However, mothers of young children also start businesses in countries characterized by supportive workfamily institutions. Sweden, for example, has witnessed 
a substantial increase in businesses started by mothers in recent years. A study on the period 2004-2008 shows that the presence of young children increases the probability of starting a business among Swedish mothers (Joona 2017). Substantial questions, therefore, remain about what factors determine business start-up by mothers of young children in contexts characterized by supportive work-family institutions, such as generous parental leave policies.

Extant theory suggests two different predictions that rest on different perspectives on gender inequality within households. One perspective-which is the predominant perspective in the current literature on women's entrepreneurship - takes gender inequality within households as given (Budig 2006; Jennings and Brush 2013). In this perspective, the mother is mainly responsible for childcare even if both parents work (McGowan et al. 2012). Thus, this perspective predicts that in countries with policies that support family-work balancesuch as Sweden - mothers of young children start businesses mainly because they are unemployed or because they are in a difficult position for finding employment with good conditions. For example, immigrants, who tend to lack language skills and local networks, may fall into this category.

The other perspective does not take gender inequality within households as given, instead arguing that policy contexts that support work-family balance are also characterized by more egalitarian relationships between partners at home (Hook 2010; Thébaud and Pedulla 2016). Thus, this perspective predicts that in countries such as Sweden, mothers start businesses because fathers make use of parental benefits and take responsibility for a larger share of childcare. Since both predictions are compelling and might coexist, it is important to investigate which factors - being unemployed or having a partner who assumes responsibility for childcarehave the strongest relationship to entrepreneurship among mothers in Sweden. This study explores these issues in a sample of mothers of young children in Sweden.

Although we use causal language when describing the two perspectives above, the data and analyses we use only allow us to examine associations between different factors-being unemployed or having a partner who takes paternity leave-and entrepreneurship among mothers. We conceptualize the Swedish context as characterized by a tool-kit of public policies intended to help both parents balance work and family and make it possible for both to work. One form of this support "is legislation granting paid parental leave and time off to care for sick children, which is available to fathers as well as mothers. Also, the government subsidization of daycare makes it possible for both parents to be employed" (Allard et al. 2011: 142-143). Within this context, we focus on examining which individual-level factors-being unemployed or having a partner who takes paternity leave-are most relevant for entrepreneurship by mothers. Thus, we are not testing the effects of specific public policies at the national level-such as parental leave policies-on gender inequality within households and/or entrepreneurship by mothers.

This paper makes the following contributions to the existing literature. While the field is dominated by studies of Anglo-Saxon cultures (Henry et al. 2015; Jennings and Brush 2013), we study the linkage between motherhood and entrepreneurship in Sweden - a context where welfare institutions and public policies are different from those in countries such as the USA, United Kingdom, and Australia. Thus, we respond to calls for studies of women's entrepreneurship in context (De Bruin et al. 2007; Welter 2011). Second, we use register data covering all mothers of newly born children and their partners in Sweden between 2000 and 2014. Prior research is either based on a few case studies (Duberley and Carrigan 2012; Ekinsmyth 2011) or survey data (Thébaud 2015). Thus, such research has not been able to identify mothers of newly born children and follow them and their partners for periods that span several years.

Understanding why and under what conditions mothers engage in business start-up in contexts characterized by supportive welfare system helps explain everyday entrepreneurship in this particular context (Baker and Welter 2017) and helps clarify the drivers of entrepreneurship among mothers. Thus, this study lies at the core of entrepreneurship research by explaining who engages in entrepreneurship and under what conditions (Shane and Venkatamaran 2000). Simply put, the topic is important for understanding the boundaries of business start-up by women who are mothers; the size of this entrepreneurial population is growing steadily. By incorporating welfare state benefits such as parental leave and its uptake by fathers, the study makes an important contribution to the literature on entrepreneurship among mothers, and it also adds new information to the international debate on parental leave. 


\section{Theoretical framework}

There is a growing body of research related to the effects of institutional-level factors on entrepreneurial activities within a country (Bruton et al. 2010; De Clercq et al. 2013), including women's entrepreneurship (Welter et al. 2014). As noted by Baughn et al. (2006: 688), "institutions provide the rules of the game, and define actors' available modes of action-constraining or empowering certain types of behavior". The institutional context in a specific country entails both formal components, e.g., laws and formal regulations, and informal components, e.g., conventions and norms of behavior (North 1990). Similarly, Scott (2007) distinguishes between regulative and normative pillars of institutions. While the regulative pillar comprises formal laws and governmental regulations and policies, the normative pillar refers to sets of expectations, within a certain context, of what constitutes appropriate behavior, such as social norms, values, and guidelines for behavior (Roberts and Greenwood 1997).

In examining the effects of institutional-level factors on women's entrepreneurship, extant research has focused on the effects of formal institutional arrangements that support work-family balance, such as parental leave, flexible work hours, and subsidized childcare. A consistent finding is that in institutional contexts that lack formal "family-friendly" policies, mothers are driven to start their own businesses as a fallback strategy to balance work and family life (Arráiz 2018; Estrin and Mickiewicz 2011; Thébaud 2015).

However, much less research attention has been devoted to what drives mothers to become entrepreneurs in institutional contexts, such as Sweden, where there are formal institutional arrangements that reduce work-family conflicts. In these contexts, mothers do not need to opt for entrepreneurship and start their own businesses as a fallback employment strategy, or plan B. Sweden is characterized as a welfare regime with an extensive family policy system (Boje and Ejrnæs 2012). The State takes responsibility for children and the elderly, providing publicly subsidized childcare centers, public schools, and universities; paid parental leave for either parent on equal terms (up to 480 days); and "the statutory right to stay home from work (also paid) with sick children for either parents - all financed through the tax system" (Ahl and Nelson 2015: 3). Also, until a child reaches the age of 8 years, parents have the statutory right to reduce their working time, although there is no payment for the reduced hours.

In the following, we propose that the specific factors that are related to entrepreneurship by mothers in contexts characterized by work-family supportive policies are directly related to two different perspectives on gender (in)equality within households, which is a critical aspect of the informal institutional context (Baughn et al. 2006).

\subsection{A mainstream view of gender inequality within households}

The predominant perspective in the research on women's entrepreneurship considers gender inequality within households as a persistent feature of most institutional contexts. This feature persists because informal institutions are subject to strong inertia (North 1990). The central premise is that even though the fastchanging world outside the home has moved towards greater gender equality, the roles of men and women inside the home have changed relatively little (Calasanti and Bailey 1991; Skolnick 2009). Throughout the world, women continue to perform "the lion's share of unpaid caring work" (Ahl and Nelson 2015:3), and domestic work and obligations, including child care, "fall disproportionately to women, even if women work equal or longer hours than their male spouses" (Baughn et al. 2006: 689).

The above observations are supported by sociological studies showing that when men and women become parents, they tend to resort to more traditional gender roles within the household (Dribe and Stanfors 2009). Lappegard (2008: 158) study of parental leave in the Nordic countries indicates that "since the common parental leave period is today considered more of a mother's right, fathers are faced with more obstacles to taking more leave". Additional research from Sweden shows that a father might not use a large share of parental leave because "he has to weigh the possible negative reactions from workmates, supervisors, and the employer against the amount of parental leave he wishes to take" (Sundström and Duvander 2002: 443).

Thus, in making career choices, mothers of young children need to take into account how to best balance their domestic and economic obligations (Jennings and McDougald 2007). In institutional contexts with formal arrangements that support work-family balance, having wage employment provides mothers with the best 
conditions for simultaneously managing such domestic and economic obligations. Indeed, the benefits of arrangements such as paid parental leave are connected to wage employment and cannot be entirely realized by mothers starting their own businesses.

Under these premises, in institutional contexts with a formal family policy system, women are pushed to start businesses mainly because they are unemployed or because they face unfavorable conditions in the labor market (Thébaud 2015), such as those experienced by immigrants who encounter more labor market obstacles than nonimmigrants due to a lack of language skills and local networks (Evans 1989). This perspective in the entrepreneurship literature is also supported by the sociological literature on the so-called welfare state paradox (Mandel and Semyonov 2006). This literature holds that by allowing reduced working hours and long parental leaves, extensive family policies contribute to preserving gender inequality within families, as they allow women to maintain their traditional role as primary nurturer and caregiver in the family. Moreover, it is argued that extensive family policies might even increase employers' discrimination against mothers, making it more difficult for mothers to find wage employment because such policies render "mothers less attractive to employers who prefer employees with an uninterrupted commitment to work" (Mun and Jung 2018: 511).

In summary, according to the mainstream view detailed above, mothers of young children in Sweden turn to entrepreneurship mainly as an economic necessitythat is, in response to unemployment and job-loss (Hughes 2003) or because they are in a position in which finding employment with full job benefits may be difficult, such as for immigrants. Thus, being unemployed and/or being an immigrant are expected to be the factors most strongly associated with entrepreneurship among mothers.

\subsection{An alternative view of gender inequality within households}

Another less visible perspective does not consider gender inequality within families as a persistent feature of most institutional contexts. Building on the assumption that institutions can change, the essence of this perspective is that formal institutional arrangements - such as extensive family-oriented policies - may contribute (at least in part) to changing informal institutions, such as traditional expectations regarding the division of responsibilities and roles between men and women within the household (Neergaard and Thrane 2011). Specifically, as supportive family policies have increased women's participation in the labor market (Schultz 1990), they have also enhanced women's independence and contributed to challenging traditional gender inequality within the household (Craig and Mullan 2011; Haas 1992; Hobson 1990; Hook 2010). In more detail, the sociological literature-e.g., gender and welfare state theories - holds that the national context and in particular welfare policies have influenced normative gender expectations about behavior, especially within the household (Hook 2010). McDonald (2000) describes this process as the 'gender revolution'. During the first part of this process, women enter the public sphere of education and employment with the help of policies (e.g., parental leave) that make women's employment and a dual breadwinner system the norm. During the second part of the process, men enter the private sphere and share "responsibility for the care of children equally with their female partners (just as women increasingly share the provider role)" (Bernhardt et al. 2008: 278).

Research has, for example, shown that "men who earn approximately the same income as their spouses perform more housework than men who are primary breadwinners" (Thébaud 2010: 332) and has discussed the "increasing convergence of sex roles" (Coverman and Sheley 1986). This type of household resembles what Giddens (2005) calls the "democratic family", in which there are no fixed norms regarding who should do what. Key family issues are subject to negotiation and joint decision-making between the parents (Ahlberg et al. 2008), and normative expectations are characterized by "double emancipation"-women can be workers as well as carers, and men can be carers as well as workers (Klinth 2002a, b). The dual-breadwinner/ dual-career model of countries such as Sweden is reflected in a new image of fatherhood (Dribe and Stanfors 2009; Jensen 2000). Paternity leave becomes particularly important because "it makes fathers available for time-inflexible housework and childcare, enabling mothers to return to the workforce sooner or invest in their career" (Patnaik 2015: 9). Research also shows that men who report bearing more responsibility and performing more hours of childcare at home also reported taking more parental leave (Haas and Hwang 2008). 
Under these premises, in institutional contexts with an extensive family policy system, such as Sweden, mothers can be expected to make career choices by negotiating with their partners who will make use of the parental benefits offered by the government (e.g., paid parental leave) and take responsibility for childcare. Hence, entrepreneurship is not necessarily a fallback strategy but may reflect the pursuit of an opportunity facilitated by the egalitarian trend within the family context (Brush and Hisrich 1991). Baughn et al. (2006: 692) discuss pull factors contributing to entrepreneurship by mothers, suggesting that "entrepreneurship may be more attractive relative to wage/salary employment in societies characterized by higher levels of gender equality".

In summary, according to this perspective, the amount of paternity leave taken by fathers is expected to be the factor most strongly associated with entrepreneurship by mothers in Sweden.

\subsection{Women's entrepreneurship in Sweden in an institutional context}

Women's business ownership in Sweden has always been a reflection of formal, regulative institutions, and market conditions. Before 1846, women could not own a business. At that time, widows and divorced or unmarried women were allowed to engage in petty trade to support themselves. Married women could control their own income in 1874, and single women became major at age 21 in 1884, but it took until 1921 before married women became major and women could vote. However, women's business ownership then increased rapidly. Women's share of business ownership was $27 \%$ in the 1930s and 1940s (Lundström 1996). In Sweden, the mom-and-pop store was a mom store-women had milk, bread, and delicatessen shops, laundries, and mangling services. The 1950s and 1960s saw the rapid rationalization of retail, and many small shops were closed. Female labor was instead absorbed by the rapidly expanding manufacturing industry but even more so by the growing public sector in the late 1960s and 1970s. Small business ownership declined overall, and women's ownership declined in particular - their share of business ownership decreased to approximately $15 \%$ in 1972. However, as small businesses took an upward turn after the oil crisis in 1973, women's share of businesses rose again, particularly in the growing service sector - by 1990, it was over $30 \%$ (Svanlund 2011). The 1990s saw another economic crisis, which was cured by drastic cuts in the public sector and the privatization of formerly government-owned operations in care, health care, and education, accompanied by government policy and programs to stimulate women to start businesses in these areas (Berglund et al. 2018). In 2016, women's share of business ownership had risen to $38 \%$. Most of these businesses were in personal or cultural services $(33 \%)$, business services $(21 \%)$, retail $(9 \%)$, care $(7 \%)$, and farming (7\%) (SCB 2018).

Women's participation in the labor force has been, and is, substantial in Sweden. In 2017, the figure for women aged 20-64 was $85 \%$, and it was $89 \%$ for men (SCB 2018). The gender pay gap has slowly diminished over the years - the weighted gap, which controls for age, educational background, full-time/part-time, sector, and occupational group, was 5\% in 2016, and the unweighted pay gap was $12 \%$ (SCB 2018). A dual breadwinner system is both the norm and a necessity.

Women's high labor market participation was made possible by several policy reforms. An important reform was the introduction of separate taxation in 1974. Before then, it sometimes did not pay for a married woman to work - her income, which was added to her husband's when doing the tax return, was consumed by a very high marginal tax rate. The family policy also changed. Beginning in the $1970 \mathrm{~s}$, public, universal daycare and preschools, as well as world-renowned academic education for preschool teachers, were established. Today, every child aged 1 has the statutory right to subsidized daycare and preschool that is affordable for everyone.

In 1974, paid parental leave that could be divided between the mother and the father as they wished replaced the former system of maternity leave. However, due to entrenched gender roles and resistance from employers, fathers' uptake of this leave was initially negligible. To stimulate more fathers to take parental leave, 30 days were earmarked for them in 1995, 60 days were earmarked in 2002, and 90 (of a total of 480) days were earmarked in 2016. The idea is that if legislation and economic incentives change, the attitudinal change will follow. In 2017, fathers used $28 \%$ of all parental leave days, so the policy seems to have worked, albeit slowly. The 480 days can be allocated as parents wish during the first 8 years of a child's life, and fathers tend to take parental leave more often when the child is a little older (SCB 2018). Parents also have the statutory right to stay home from work with a sick child, while 
receiving pay, for a maximum of 60 days per year. Men took 38\% of such days in 2017 (SCB 2018).

Time studies show that Swedish cohabiting women perform approximately $55 \%$ of unpaid work, including housework, dependent care, maintenance, shopping, and commuting for work, but cohabiting parents of small children spend much more time on unpaid work than others: $39 \mathrm{~h}$ per week for women and $32 \mathrm{~h}$ per week for men compared to 26 and $21 \mathrm{~h}$ per week, respectively, for all parents (SCB 2018).

All in all, Sweden has a number of formal institutions that make employment the norm for women. It should be mentioned that remuneration in the parental leave system is tied to one's income from employment. The parental leave remuneration for the first 390 days is $80 \%$ of one's salary, with a salary cap of SEK 465,000 (approximately USD 50,000). Many employers pay the difference between $80 \%$ and $90 \%$, irrespective of income level, i.e. without a cap, so parental leave remuneration covers a substantial part of one's salary, even for those individuals who are well-paid. A person must have been employed approximately 8 months continuously before the birth of the child to obtain this remuneration. One cannot work when one takes parental leave days. Therefore, combining business ownership with parental leave is more difficult — one must leave the business to someone else to run if taking parental leave. However, there is also some evidence that formal institutions established in Sweden might contribute to altering informal institutions, such as the gender system within the household, in a comparatively egalitarian direction in which men and women share housework and men take parental leave days.

These circumstances make Sweden the ideal context for exploring the two aforementioned views of the intersection of entrepreneurship and motherhood: the "mainstream" view and an "alternative" view.

\section{Method}

\subsection{Sample}

In order to conduct the study, we constructed a longitudinal dataset by combining four longitudinal Swedish databases: (1) the Longitudinal Integration Database for Health Insurance and Labor Market Studies (LISA for its initials in Swedish), which provides yearly data on all residents of Sweden, including family relationships; (2) the Jobbregistret (work register) database, which provides yearly data on all Swedish inhabitants' income sources and work activities; (3) the Labor Market Statistics (known by the acronym RAMS in Swedish) database, which provides yearly data on all firms registered in Sweden; and (4) the multi-generational-database, which provides information on couples (i.e., if they are married or if they are living together and have children together) as well as on biologically linked families (i.e., parents and children). As these databases provided by Statistics Sweden contain annual information about individuals, our sample and analyses are based on annual observations of data. These are official statistics, which are considered highly accurate and reliable (cf. Baù et al. 2017; Wennberg et al. 2011; Wiklund et al. 2013).

To identify a sample of mothers of newly born children, we started with an initial sample of all children born in Sweden between 2000 and 2014. From these data, we identified the mothers - 16 to 55 years of age — of each newly born child and collected longitudinal information about their work status (e.g., employed or unemployed), background (e.g., immigrant), parental benefits (e.g., paid parental leave), work experience, education, income, and use of parental benefits. We collected identical information about the women's partners.

We used a Cox proportional hazard model to test what factors explain the likelihood that mothers will start a business (Cameron and Trivedi 2013; Cleves et al. 2008; Rabe-Hesketh and Skrondal 2008; Royston and Lambert 2011). This approach allows an eventhistory analysis incorporating longitudinal data with time-varying variables to predict both the timing and the occurrence of an event (Allison 2014); it also analyzes the influence of predictor variables on the occurrence or nonoccurrence and timing of specific events (Morita et al. 1993). Our model considers semiparametric proportional hazard regressions. Thus, the hazard rate is calculated as the product of an arbitrary and unspecified baseline hazard rate $h_{0}(t)$. The vector includes a number of covariates and regression coefficients to be estimated $\mathrm{x}_{\mathrm{i}} \beta$ (for details see, e.g., Efron 1977: 229-244).

$h\left(t \mid x_{i}\right)=h_{0}(t) \cdot \exp \left(x_{i}^{\prime} \beta\right)$

However, as our analysis is based on annual data, we are only able to observe failures in a discrete manner 
('ties'). Our dependent variable is dummy coded to indicate whether the mother starts a business. Indeed, we only know which and how many mothers become entrepreneurs from year to year; we cannot distinctly order their entry times (i.e. failures) within each period (see Cox and Oakes 1984). Therefore, we adopted the method of Efron (1977) within the Cox proportional hazard framework to correct the partial likelihood function in order to cope with the existence of ties and to obtain unbiased and consistent estimates.

In particular, we identified as a fail event the entrepreneurial entry of a mother of a newly born child during a period of up to 8 years after the child's birth. We chose 8 years as the maximum period for following each mother because this is the length of time during which parents can make use of paid parental leave in Sweden. In the period 2000-2014, we identified about 1 million mothers of newly born children. Out of this million, 60,000 started a business during the time they (and their child's fathers) could have made use of parental benefits.

Further, we excluded those mothers who were already engaged in entrepreneurial activities before the birth of the child. Moreover, as we make predictions based on gendered roles within the household (e.g., gender inequality within the household), we selected only those mothers who were living together with their partners in a household. This selection yielded a final sample of more than 700,000 mothers. Out of these, 45,000 mothers started a business in the given period.

\subsection{Dependent and independent variables}

Entrepreneurial entry was measured using a dummy variable. We analyzed whether the mother entered entrepreneurship (coded " 1 ") or not (coded " 0 ") in the 8 years following the birth of the child. Thus, we have a separate dummy variable for every year since the child's birth.

In order to test the predictions of the mainstream view, we employed two independent variables in our analysis: the mother's unemployment and the mother's immigrant status. Mother's unemployment was dummy coded as " 1 " if the mother was unemployed for at least 1 month in the year before the birth of the child, " 0 " if she was permanently employed. Similarly, as we want to identify women who face labor-market obstacles due to their lack of language skills and local networks, we test for mother's immigrant status (Evans 1989) coded as
" 1 " when the mother was born in a country other than Sweden, "0" otherwise.

In order to test the prediction of the alternative view, we considered one independent variable: paid paternity leave for the partner. This variable was calculated as the partner's parental benefits paid in the year, divided by the income of the individual's partner in the same year.

\subsection{Control variables}

We introduced several control variables at the individual, household, and regional levels that could affect our results.

At the individual level, we accounted for the mother's age, years of education, prior entrepreneurial experience, parental leave, and the number of offspring. We controlled for mother's age because it may affect the probability of engaging in entrepreneurial activities (Langowitz and Minniti 2007). Then, as human capital affects the propensity for starting a business, we controlled for mother's years of education (Ucbasaran et al. 2003), coded as a continuous variable that indicates the number of years a person spent in school and at university. Research has shown that education is an important factor in explaining a person's decision to start a business, especially for women in high-income countries (Allen et al. 2007). Similarly, it has been shown that prior experiences as an entrepreneur might provide important skills and social capital that could be exploited in a novel initiative (Baù et al. 2017); thus, we controlled for mother's prior entrepreneurial experience, dummy coded as " 1 " if the mother had an entrepreneurial activity terminated or sold before the birth of the child, " 0 " otherwise. Moreover, to provide the complementary perspective of the partner's parental leave used as an independent variable, we control for the mother's parental leave, calculated as the mother's parental benefits paid in the year, divided by the mother's individual's income in the same year. Finally, we controlled for the number of offspring in the household, as the number of children might change the family structure by, for example, introducing additional time constraints and parental responsibilities.

At the household level, we included the partner's unemployment, immigrant status, years of education, prior entrepreneurial experience, and family disposable income. In order to complement the independent variables used for testing the mainstream view within the household, we controlled for partner's unemployment, 
dummy coded as " 1 " if the partner was unemployed for at least 1 month in the year before the birth of the child, " 0 " if permanently employed. Similarly, we controlled for partner's immigrant status, coded as " 1 " when the partner was born in a country other than Sweden, "0" otherwise. Thus, given that the partner's education might affect the 'double emancipation' of both women and men as workers as well as in their careers (Klinth 2002a, b), we controlled for partner's years of education, which we coded as a continuous variable that indicates the number of years a person spent in school and at university. Moreover, we controlled for partner's entrepreneurial experience, dummy coded as " 1 " if the partner is an entrepreneur, " 0 " otherwise. The variable is lagged 1 year.

Finally, the family business literature has largely investigated the propensity of families to self-finance entrepreneurial initiatives. Indeed, a large household income may generate slack resources that favor entrepreneurial initiatives by individual members (Alsos et al. 2014). Thus, we controlled for the logarithm of the household's disposable income. The variable is calculated by Statistics Sweden as the sum of the individual disposable incomes of the household members, expressed in hundreds of SEK. ${ }^{1}$ The variable is lagged 1 year.

Further, we controlled for the characteristics of the municipality of the household's residence, which can affect business start-up. Extant research has observed that start-ups per capita are relatively more concentrated in metropolitan areas and least frequent in rural areas (Westlund 2011). Therefore, following the work of Westlund et al. (2014) and Nilsson (2015), we separated Swedish municipalities into two categories and coded municipality type as a dummy variable equal to " 1 " to indicate an urban context, which includes both metropolitan and urban municipalities that supply a large variety of services to the individuals and firms based in that location. Thus, we coded the rural context as " 0 ", which includes rural and sparsely populated rural municipalities that host a limited variety of services.

\footnotetext{
${ }^{1}$ Individual disposable income is calculated by considering the following: factor income; taxable positive transfers; tax-free positive transfers and negative transfers. When the value was negative, we recoded as " 0 ". This variable includes the benefits generated by the household's wealth, both as factor income (e.g. profit investments, dividends and capital gain) and as taxable positive transfers (e.g., income from private pensions and investment funds).
}

Finally, we controlled for time by including the number of years passed since the birth of the child.

\subsection{Controlling for self-selection}

In this study, we identified two potential sources of sample selection bias. The first one is induced by having or not having a child within the time frame (2000-2014) chosen for the study. Thus, using Heckman's (1979) two-step procedure, we identified the mother's status of being a single child as an instrumental variable for calculating the inverse Mills ratio to include in the analyses. The instrumental variable must be correlated with the first-stage probit model's outcome (i.e., having a child) but not with the second-stage model's outcome (i.e., mother's entrepreneurial entry) (Kennedy 2008; Wooldridge 2002). In detail, we calculated a probit regression per each year of our sampling period, comparing all women who had a child in the given year with those in the age range 16-55 who had no children in the same year. ${ }^{2}$ Therefore, we predicted an inverse Mill's ratio from each of the year-based probit models that we included in our analysis (i.e., Mill's no children).

The second potential sample selection bias is induced by the choice to include only mothers living in a household with their partner, thus excluding single and divorced mothers. As we mentioned, this choice was driven by our interest in testing the two views of gender inequality within the household. Nonetheless, this choice has to be addressed by using Heckman's (1976) two-step procedure. In this case, the instrumental variable used for calculating the first-stage probit model's outcome was the mother's divorced parents, dummy coded as " 1 " in the affirmative case. Indeed, Mustonen et al. (2011) found that in Finland, women and men from divorced families are more often divorced or separated at the age of 32 years than are those from nondivorced families. Moreover, they also found that parental divorce is associated with poorer intimate relationship quality for women. Thus, we use the predicted inverse Mill's ratio in our analysis (i.e., Mill's no partner).

\footnotetext{
$\overline{2}$ Due to space constraints, results from the first step of this procedure are not reported but are available upon request.
} 


\section{Results}

We present descriptive statistics and correlations in Tables 1 and 2. Inspection of the variance inflation factors (VIFs) showed that multicollinearity is not a concern in the study. All of the VIF coefficients are lower than 2.50 (mean 1.40) (Belsley et al. 2005; Kutner et al. 2004).

Our purpose was to test two different predictions that can be found in the literature. The mainstream view predicts that the mother's unemployment status and the mother's immigrant background are the main predictors of entrepreneurial entry. The alternative view predicts that the partner's paid parental leave is the main predictor of entrepreneurial entry. We report the results of the Cox proportional hazard model in Table 3.

In line with the predictions of the mainstream view, the results in model 2 show that both the mother's unemployment (coeff. $=1.03 ; p>0.01$ ) and the mother's immigrant status (coeff. 1.06; $p>0.000$ ) have positive and significant effects on entrepreneurial entry. In addition, in line with the prediction of the alternative view, model 2 also shows also that the partner's paid paternity leave has a positive and significant effect (coeff. $=1.58$; $p>0.000$ ) on entrepreneurial entry.

These findings confirm that both views are compelling and may co-exist. Nonetheless, we are still interested in knowing which of the independent variables has the strongest impact on entrepreneurial entry. To determine this, we tested the difference among coefficients.
We found that partner's paid paternity leave is significantly larger than both mother's unemployment $\left(\mathrm{chi}^{2}=\right.$ $36.90 ; p>0.000)$ and mother's immigrant status $\left(\mathrm{chi}^{2}=\right.$ 42.33; $p>0.000)$. These tests demonstrate that the amount of paternity leave taken by fathers is the key factor explaining the entrepreneurial entry of mothers of young children in Sweden.

Looking at our control variables, at the individual level, we accounted for mother's age, years of education, prior entrepreneurial experience, parental leave, and the number of offspring. Our results show that that mother's age positively impacts the propensity to engage in entrepreneurial activities during the maternity period (coeff. $=1.04 ; p>0.000$ ). Similarly, the mother's prior entrepreneurial experience (coeff. $=1.40$; $p>0.000$ ) also exerts a positive effect. By contrast, several factors negatively impact the mother's entrepreneurial entry, such as mother's years of education (coeff. $=.93 ; p>0.000)$, mother's parental leave (coeff. $=.62 ; p>0.000$ ), and number of offspring (coeff. $=.76 ; p>0.000)$.

At the household level, we considered the effect of the partner's unemployment, immigrant status, years of education, prior entrepreneurial experience, and family disposable income. On the one hand, our results show that several factors positively influence mothers' entrepreneurial entry, such as partner's immigrant status (coeff. $=1.07 ; p>0.000$ ), partner's years of education (coeff. $=1.05 ; p>0.000$ ), and partner's entrepreneurial

Table 1 Descriptive statistics

\begin{tabular}{|c|c|c|c|c|c|}
\hline & Mean & Median & SD & Min & Max \\
\hline Mother's entrepreneurial entry & 0.01 & 0.00 & 0.10 & 0.00 & 1.00 \\
\hline Mother's unemployment & 0.24 & 0.00 & 0.43 & 0.00 & 1.00 \\
\hline Mother's immigrant status & 0.15 & 0.00 & 0.36 & 0.00 & 1.00 \\
\hline Partner's parental leave & 0.01 & 0.00 & 0.05 & 0.00 & 5.92 \\
\hline Mother's age & 34.17 & 34.00 & 5.37 & 17.00 & 61.00 \\
\hline Mother's years of education & 13.10 & 13.00 & 2.31 & 6.00 & 21.00 \\
\hline Mother's prior entrepreneurial experience & 0.02 & 0.00 & 0.13 & 0.00 & 1.00 \\
\hline Mother's parental leave & 0.08 & 0.00 & 0.22 & 0.00 & 13.59 \\
\hline Number of offspring & 1.24 & 1.00 & 0.43 & 1.00 & 2.00 \\
\hline Partner's unemployment & 0.23 & 0.00 & 0.42 & 0.00 & 1.00 \\
\hline Partner's immigrant status & 0.14 & 0.00 & 0.34 & 0.00 & 1.00 \\
\hline Partner's years of education & 12.61 & 12.00 & 2.40 & 0.00 & 21.00 \\
\hline Partner's entrepreneurial experience & 0.08 & 0.00 & 0.28 & 0.00 & 1.00 \\
\hline Household's disposable income (log) & 7.51 & 8.18 & 2.31 & 0.00 & 14.43 \\
\hline
\end{tabular}




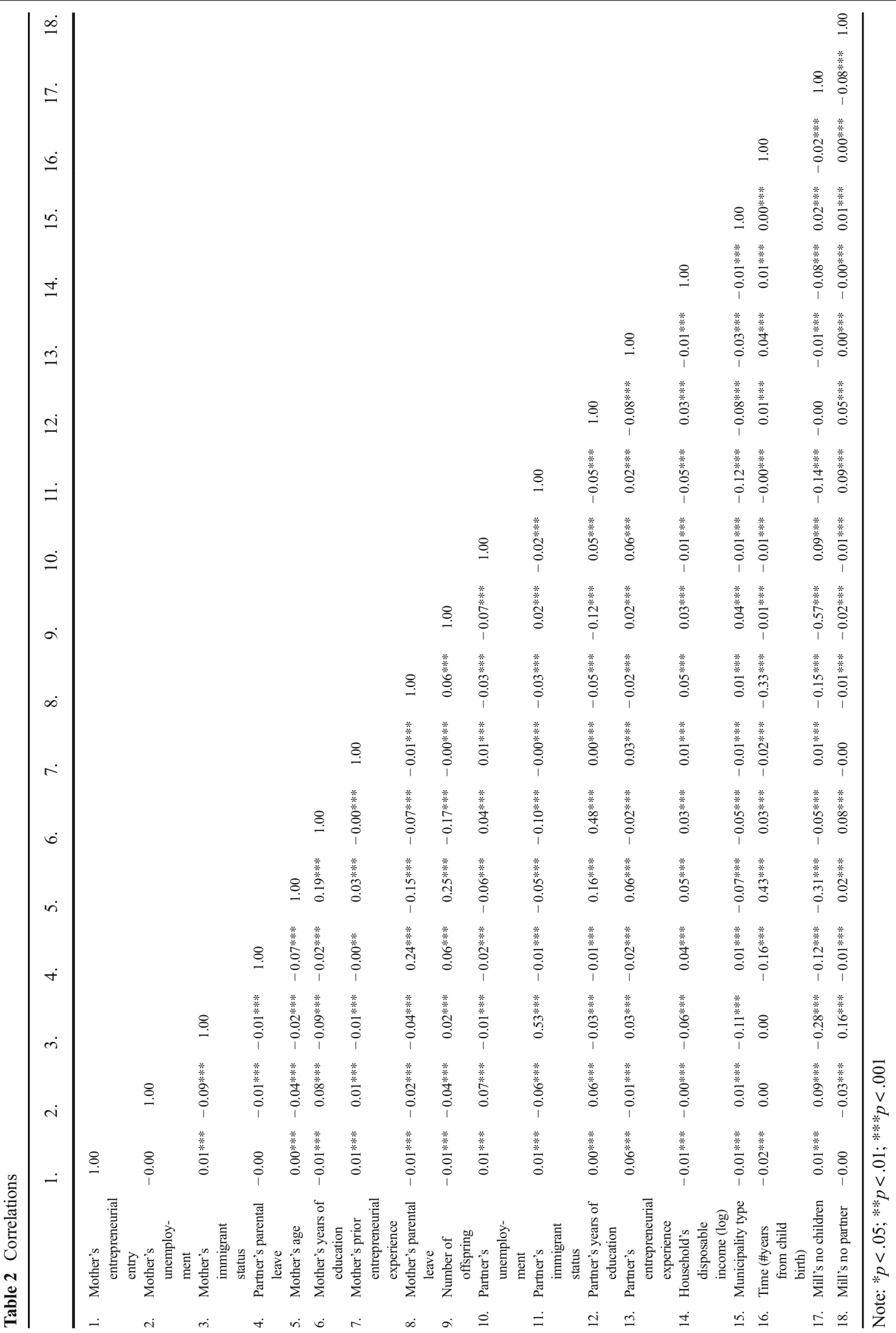


Table 3 Cox proportional hazards model: entrepreneurial entry

\begin{tabular}{|c|c|c|}
\hline & 1. & 2. \\
\hline Mother's age & $1.04 * * *(.01)$ & $1.04 * * *(.01)$ \\
\hline Mother's years of education & $.93 * * *(.01)$ & $.93 * * *(.01)$ \\
\hline Mother's prior entrepreneurial experience & $1.41 * * *(.04)$ & $1.40 * * *(.04)$ \\
\hline Mother's parental leave & $.62 * * *(.02)$ & $.62 * * *(.02)$ \\
\hline Number of offspring & $.76 * * *(.01)$ & $.76 * * *(.01)$ \\
\hline Partner's unemployment & $1.02+(.01)$ & $1.02(.01)$ \\
\hline Partner's immigrant status & $1.09 * * *(.01)$ & $1.07 * * *(.02)$ \\
\hline Partner's years of education & $1.05 * * *(.01)$ & $1.05 * * *(.01)$ \\
\hline Partner's entrepreneurial experience & $3.57 * * *(.04)$ & $3.57 * * *(.04)$ \\
\hline Household's disposable income (log) & $.88 * * *(.01)$ & $.88 * * *(.01)$ \\
\hline Municipality type & $.99 * * *(.01)$ & $.99 * * *(.01)$ \\
\hline Mother's unemployment & & $1.03 * *(.01)$ \\
\hline Mother's immigrant status & & $1.06 * * *(.02)$ \\
\hline Partner's parental leave & & $1.58 * * *(.14)$ \\
\hline Time (\#years from child birth) & $.83 * * *(.01)$ & $.83 * * *(.01)$ \\
\hline Mill's no children & $.92 * *(.02)$ & $.96(.03)$ \\
\hline Mill's no partner & $.68 * *(.09)$ & $.64 * *(.09)$ \\
\hline Log likelihood & $-564,945.00$ & $-591,235.28$ \\
\hline LR $\mathrm{Chi}^{2}$ & $19,855.33 * * *$ & $21,119.33 * * *$ \\
\hline AIC & $1,129,918$ & $1,129,878$ \\
\hline $\mathrm{BIC}$ & $1,130,104$ & $1,130,100$ \\
\hline Nr. of yearly observations & $4,370,648$ & $4,370,648$ \\
\hline Nr. of maternities & 743,684 & 743,684 \\
\hline Nr. entrepreneurial entry & 45,548 & 45,548 \\
\hline
\end{tabular}

Note: $* p<.05 ; * * p<.01 ; * * * p<.001$. Hazard ratio reported. Standard errors are in parentheses

AIC Akaike's information criterion, BIC Bayesian information criterion. Gradually smaller values over models denote improved model fit

experience $($ coeff. $=3.57 ; p>0.000)$. Partner's unemployment, however, appears to be not significant in our analysis. On the other hand, a higher household disposable income negatively impacts the mother's propensity to undertake entrepreneurial activities (coeff. $=.88$; $p>0.000$ ).

Finally, we controlled for the characteristics of the municipality of the household's residence, which can affect business start-up. Living in a rural area negatively affects the mother's entrepreneurial entry (coeff. $=.99$; $p>0.000)$.

\subsection{Robustness tests}

We also performed some important additional robustness tests to verify our main results. First, looking at the immigrant background of both the mother and the partner, we considered different alternatives. (1) We distinguished between Scandinavian (i.e., Sweden, Finland, Norway, and Denmark) versus non-Scandinavian backgrounds; (2) we distinguished between European (i.e., the 28 members of the European Union) versus non-European backgrounds; (3) we distinguished between individuals born in the European Union or the United States versus other countries. The results were consistent with our analysis, validating our results in comparing the first group (including Swedish-born mothers) with the control group.

Second, in considering unemployment status, we tested alternative definitions calculated with a 1-year lag. We considered (1) unemployment status in the year before; (2) number of years of continuous unemployment; (3) number of months of unemployment in the year before; (4) number of months of continuous 
unemployment. Also in this case, the results were significant and consistent with our main analysis.

Third, we conducted an additional robustness test to proxy the status of economic need. In particular, we considered whether the family income was below the poverty line in the previous year. Persistent risk of poverty refers to persons living in a household where the equivalized disposable income is below $60 \%$ of the national median during the reference year and during at least two out of the preceding 3 years $\left(\right.$ Eurostat $\left.^{3}\right)$. This additional test provided results consistent with the mother's unemployment status.

Fourth, we also measured household disposable income by considering the individual disposable income of the mother and her partner. The results are consistent and significant.

Finally, during the review process, we recognized the opportunity to test for same-sex couples. We isolated in our dataset approximately 1400 couples in which mothers shared a household with a female partner. In these households, we observe about 50 events of entrepreneurial entry of mothers. Excluding same-sex couples from the dataset, coefficients and significance levels were consistent with our full model.

\section{Discussion}

There is a growing interest in the institutional-level factors that affect women's entrepreneurship (Ahl and Nelson 2015; Baughn et al. 2006; Estrin and Mickiewicz 2011; Welter et al. 2014). Drawing on the work-family interface literature, we focus on an institutional context - Sweden - that is characterized by formal policies that support work-family balance and investigate what factors have the strongest relationship with entrepreneurship among mothers. In doing so, we complement past research on women's entrepreneurship, which has mainly focused on institutional contexts where institutional policies supporting work-family balance are lacking (Arráiz 2018; Duberley and Carrigan 2012; Ekinsmyth 2011; Richomme-Huet et al. 2013).

We consider two different views of gender inequality within households, each of which suggests different factors that may be related to entrepreneurship by mothers. One perspective takes gender inequality as a

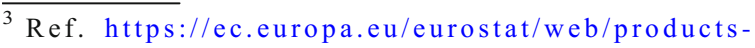
datasets/product?code $=$ tespm 150
}

persistent feature of most households and suggests that the primary factor influencing entrepreneurship by mothers is the lack of employment with good conditions. The other perspective assumes more egalitarian relationships at home and suggests that paternity leave taken by fathers is the primary factor influencing entrepreneurship by mothers.

Our results confirm that being unemployed or being an immigrant are associated with entrepreneurship among mothers. Mothers who have stable employment are less likely to start a business, confirming that employment is the norm among mothers of young children in an institutional context with policies that support work-family balance. Similarly, immigrant motherswho may lack language skills and social networks for finding employment with good conditions - are more likely to start a business than nonimmigrant mothers.

However, contrary to the mainstream view, our findings show that the amount of paternity leave taken by the mothers' partners has a stronger association with entrepreneurship by mothers in Sweden than does being unemployed or immigrant status. These findings are consistent with the alternative view of gender inequality within households, which suggests that formal institutions, such as family policies, might have altered informal institutions, such as normative expectations within households, making a nongendered division of parental leave an important factor for understanding entrepreneurship among mothers. For example, researchers have begun to point out that younger Swedish fathers see paternity leave as a natural way to gain 'hands-on fatherhood' experience (Bernhardt 2004) and become more actively involved in childcare (Björnberg 2002; Sundström and Duvander 2002).

\subsection{Implications and suggestions for future research}

Our study provides important theoretical and practical implications. First, our study contributes to the research on women's entrepreneurship and work-family balance. Studies in this tradition hold that mothers are less likely to pursue entrepreneurship "because they lack attractive employment options in contexts in which supportive institutions are in place" (Thébaud 2015: 671). Instead, our study shows that while lack of good employment options plays a role in explaining entrepreneurship by mothers in contexts characterized by supportive workfamily policies, the amount of paternity leave taken by fathers is also an important factor. Thus, our study 
challenges the main view within this literature that "women are expected to be the primary nurturer and caregiver in the family, giving priority to serving the needs of any descendants" [...] while "men are expected to be the good economic provider for the families" (Jennings and McDougald 2007: 752). Going forward, our study shows the importance of a contextualized perspective on entrepreneurship. While the current literature on work-family balance within the women's entrepreneurship literature has begun to compare women's entrepreneurship across different institutional contexts (Estrin and Mickiewicz 2011; Noseleit 2014; Thébaud 2015), some of the key assumptions underlying this research - such as gendered roles within householdsare very a-contextual.

More generally, our study contributes to the institutional perspective on female entrepreneurship by highlighting the interplay between formal and informal institutions within one specific context (Baughn et al. 2006; Estrin and Mickiewicz 2011; Welter et al. 2014). Specifically, our study shows that formal institutions that support work-family balance might have also contributed to altering gendered expectations of roles and responsibilities within households and thus provided specific normative support for women's entrepreneurship by making it socially acceptable - or even the norm-for fathers to assume the role of the main child carer.

Our study also has important policy implications. Our findings can also be discussed with regard to the start-up propensity of women in general. Our findings suggest that institutional arrangements - such as a wellfunctioning parental leave system - that have facilitated mothers' participation in economic activity might also enhance mothers' opportunities to become entrepreneurs as long as their partners become active childcarers. Thus, while the study's findings speak in favor of parental leave schemes that are gender-neutral - that is, parental leave benefits that can be transferred between partners - they also show that it is important that such transfers take place within the household and that fathers take paternal leave.

Beyond Sweden, our findings are also relevant for other countries that wish to promote women's pursuit of opportunity-based entrepreneurship. We flip the traditional focus on barriers to women's entrepreneurshipand how to alleviate or remove them-to inspire policymakers to consider an enabler of women's entrepreneurship -i.e., the parental leave taken by fathers.
Our approach also underscores more specifically the importance of family policies in general and parental leave systems in particular.

While offering a new perspective on women's entrepreneurship, our study has limitations that offer opportunities for future research. We used secondary data; therefore, we cannot truly capture gender dynamics within the household. Additional research might use longitudinal qualitative data to better capture such dynamics. Our research design focuses only on mothers who live with their partners in the same household. We have chosen this approach because we were interested in contrasting different views on gender inequality within households. Additional studies should expand our research by also investigating single mothers, divorced couples, and different or extended types of households.

Our study opens up a wide array of research opportunities. We offer the following suggestions. First, our study shows that the participation of the partner in the division of childcare (e.g., the use of parental leave) and employment conditions are important factors for women entering into entrepreneurship. Future research should examine whether the same pattern is observed among men. Second, given that women's childbearing and child-rearing are often associated with a 'motherhood penalty' (Correll et al. 2007), research should explore any career and earning consequences for men actively using the parental leave. For example, would men be entitled to 'fatherhood bonuses' or subjected to a 'fatherhood penalty'? Third, research exploring effective mechanisms contributing to the change in normative expectations regarding the nongendered division of housework and family care and its impact on entrepreneurship activity among both men and women would help further our contextualized understanding of the phenomenon. As such, our research encourages more studies on entrepreneurship to adopt a household perspective (Carter 2011) when exploring the motivation for entering entrepreneurship.

Funding Information Open access funding provided by Jönköping University.

Open Access This article is distributed under the terms of the Creative Commons Attribution 4.0 International License (http:// creativecommons.org/licenses/by/4.0/), which permits unrestricted use, distribution, and reproduction in any medium, provided you give appropriate credit to the original author(s) and the source, provide a link to the Creative Commons license, and indicate if changes were made. 


\section{References}

Ahl, H., \& Nelson, T. (2015). How policy positions women entrepreneurs: A comparative analysis of state discourse in Sweden and the United States. Journal of Business Venturing, 30(2), 273-291.

Ahlberg, J., Roman, C., \& Duncan, S. (2008). Actualising the 'democratic family'? Swedish policy rhetoric versus family practices, Social Politics: International Studies in Gender, State \& Society, 15(1), 79-100.

Allard, K., Haas, L., \& Hwang, C. P. (2011). Family-supportive organizational culture and fathers' experiences of workfamily conflict in Sweden. Gender, Work and Organization, 18(2), 141-157.

Allen, I. E., Langowitz, N., \& Minniti, M. (2007). Global entrepreneurship monitor. 2006 report on women and entrepreneurship.

Allison, P. D. (2014). Event history and survival analysis: Regression for longitudinal event data (Vol. 46). SAGE publications.

Alsos, G. A., Carter, S., \& Ljunggren, E. (2014). Entrepreneurial families and households (pp. 165-178). London: The Routledge Companion for Entrepreneurship. Routledge.

Anxo, D., \& Ericson, T. (2015). Self-employment and parental leave. Small Business Economics, 45(4), 751-770.

Arráiz, I. (2018). Time to share the load: Gender differences in household responsibilities and business profitability. Small Business Economics, 51(1), 57-84.

Baù, M., Sieger, P., Eddleston, K. A., \& Chirico, F. (2017). Fail but try again? The effects of age, gender, and multiple-owner experience on failed Entrepreneurs' reentry. Entrepreneurship Theory and Practice, 41(6), 909-941.

Baughn, C. C., Chua, B. L., \& Neupert, K. E. (2006). The normative context for women's participation in entrepreneruship: A multicountry study. Entrepreneurship Theory and Practice, 30(5), 687-708.

Belsley, D. A., Kuh, E., \& Welsch, R. E. (2005). Regression diagnostics: Identifying influential data and sources of collinearity (Vol. 571). John Wiley \& Sons.

Berglund, K., Ahl, H., Pettersson, K., \& Tillmar, M. (2018). Women's entrepreneurship, neoliberalism and economic justice in the postfeminist era: A discourse analysis of policy change in Sweden. Gender, Work and Organization, 25(5), 531-556.

Bernhardt, E. (2004). Is the Second Demographic Transition a useful concept for demography? Vienna Yearbook of Population Research, 25-28.

Bernhardt, E., Noack, T., \& Lyngstad, T. H. (2008). Shared housework in Norway and Sweden: Advancing the gender revolution. Journal of European Social Policy, 18(3), 275-288.

Björnberg, U. (2002). Ideology and choice between work and care: Swedish family policy for working parents. Critical Social Policy, 22(1), 33-52.

Boje, T. P., \& Ejrnæs, A. (2012). Policy and practice: The relationship between family policy regime and women's labour market participation in Europe. International Journal of Sociology and Social Policy, 32(9/10), 589-605.

Brush, C. G., \& Hisrich, R. D. (1991). Antecedent influences on womenowned businesses. Journal of Managerial Psychology, 6(2), 9-16.
Brush, C., Ali, A., Kelley, D., \& Greene, P. (2017). The influence of human capital factors and context on women's entrepreneurship: Which matters more? Journal of Business Venturing Insights, 8, 105-113. https://doi.org/10.1016/j. jbvi.2017.08.001.

Bruton, G. D., Ahlstrom, D., \& Li, H. L. (2010). Institutional theory and entrepreneurship: Where are we now and where do we need to move in the future? Entrepreneurship Theory and Practice, 34(3), 421-440.

Budig, M. J. (2006). Intersections on the road to self-employment: Gender, family and occupational class. Social Forces, 84(4), 2223-2239.

Calasanti, T. M., \& Bailey, C. A. (1991). Gender inequality and the division of household labor in the United States and Sweden: A socialist-feminist approach. Social Problems, 38(1), 34 53.

Cameron, A. C., \& Trivedi, P. K. (2013). Regression analysis of count data (Vol. 53). Cambridge university press.

Cleves, M., Gould, W., Gould, W. W., Gutierrez, R., \& Marchenko, Y. (2008). An introduction to survival analysis using Stata. Stata press.

Correll, S. J., Benard, S., \& Paik, I. (2007). Getting a job: Is there a motherhood penalty? American Journal of Sociology, 112(5), 1297-1338.

Coverman, S., \& Sheley, J. F. (1986). Change in men's housework and child-care time, 1965-1975. Journal of Marriage and the Family, 413-422.

Craig, L., \& Mullan, K. (2011). How mothers and fathers share childcare: A cross-national time-use comparison. American Sociological Review, 76(6), 834-861.

De Bruin, A., Brush, C. G., \& Welter, F. (2007). Advancing a framework for coherent research on women's entrepreneurship. Entrepreneurship Theory and Practice, 31(3), 323-339.

De Clercq, D., Lim, D. S., \& Oh, C. H. (2013). Individual-level resources and new business activity: The contingent role of institutional context. Entrepreneurship Theory and Practice, $37(2), 303-330$.

Dribe, M., \& Stanfors, M. (2009). Does parenthood strengthen a traditional household division of labor? Evidence from Sweden. Journal of Marriage and Family, 71(1), 33-45.

Duberley, J., \& Carrigan, M. (2012). The career identities of 'mumpreneurs': Women's experiences of combining enterprise and motherhood. International Small Business Journal, 0266242611435182.

Efron, B. (1977). The efficiency of Cox's likelihood function for censored data. Journal of the American Statistical Association, 72(359), 557-565.

Ekinsmyth, C. (2011). Challenging the boundaries of entrepreneurship: The spatialities and practices of UK 'Mumpreneurs'. Geoforum, 42(1), 104-114.

Estrin, S., \& Mickiewicz, T. (2011). Institutions and female entrepreneurship. Small Business Economics, 37(4), 397.

Evans, M. (1989). Immigrant entrepreneurship: Effects of ethnic market size and isolated labor pool. American Sociological Review, 950-962.

Giddens, A. (2005). The global revolution in family and personal life. Family in transition, 13, 26-31.

Giménez, D., \& Calabrò, A. (2017). The salient role of institutions in Women's entrepreneurship: A critical review and agenda for future research. International Entrepreneurship and Management Journal, 1-26. 
Haas, L. (1992). Equal parenthood and social policy: A study of parental leave in Sweden. SUNY Press.

Heckman, J. J. (1979). oSample selection Bias as a specification error. Econometrica, 47(1), 153-161.

Henry, C., Foss, L., \& Ahl, H. (2015). Gender and entrepreneurship approaches: A methodological review. International Small Business Journal, 33, 649-666.

Hobson, B. (1990). No exit, no voice: Women's economic dependency and the welfare state. Acta Sociologica, 33(3), 235250.

Hook, J. L. (2010). Gender inequality in the welfare state: Sex segregation in housework, 1965-2003. American Journal of Sociology, 115(5), 1480-1523.

Hughes, K. D. (2003). Pushed or pulled? Women's entry into selfemployment and small business ownership. Gender, Work and Organization, 10(4), 433-454.

Jennings, J. E., \& Brush, C. G. (2013). Research on women entrepreneurs: Challenges to (and from) the broader entrepreneurship literature? The Academy of Management Annals, $7(1), 663-715$.

Jennings, J. E., \& McDougald, M. S. (2007). Work-family interface experiences and coping strategies: Implications for entrepreneurship research and practice. Academy of Management Review, 32(3), 747-760.

Jensen, P. H. (2000). The Danish Leave-of-Absence schemes: Origins, functioning and effects from a gender perspective. Aalborg Universitetsforlag Centre for Comparative Welfare State Studies Working Paper, 19/2000.

Joona, P. A. (2017). Are mothers of young children more likely to be self-employed? The case of Sweden. Review of Economics of the Household, 15(1), 307-333.

Kennedy, P. (2008). A guide to modern econometrics.

Klinth, R. (2002a). Göra pappa med barn. Umeå: Boréa.

Klinth, R. (2002b). Göra pappa med barn: Den svenska pappapolitiken 1960-1995. Boréa.

Kutner, M. H., Nachtsheim, C., \& Neter, J. (2004). Applied linear regression models. McGraw-Hill/Irwin.

Langowitz, N., \& Minniti, M. (2007). The entrepreneurial propensity of women. Entrepreneurship Theory and Practice, 31(3), 341-364.

Lappegard, T. (2008). Changing the gender balance in caring: Fatherhood and the division of parental leave in Norway. Population Research and Policy Review, 27(2), 139-159.

Lundström, T. (1996). The state and voluntary social work in Sweden. Voluntas: International Journal of Voluntary and Nonprofit Organizations, 7(2), 123-146.

Mandel, H., \& Semyonov, M. (2006). A welfare state paradox: State interventions and women's employment opportunities in 22 countries. American Journal of Sociology, 111(6), 1910-1949.

McDonald, P. (2000). Gender equity in theories of fertility transition. Population and Development Review, 26(3), 427-439.

McGowan, P., Redeker, C. L., Cooper, S. Y., \& Greenan, K. (2012). Female entrepreneurship and the management of business and domestic roles: Motivations, expectations and realities. Entrepreneurship \& Regional Development, 24(12), 53-72.

Morita, J. G., Lee, T. W., \& Mowday, R. T. (1993). The regressionanalog to survival analysis: A selected application to turnover research. Academy of Management Journal, 36(6), 14301464.
Mun, E., \& Jung, J. (2018). Policy generosity, employer heterogeneity, and Women's employment opportunities: The welfare state paradox reexamined. American Sociological Review, 83(3), 508-535.

Mustonen, U., Huurre, T., Kiviruusu, O., Haukkala, A., \& Aro, H. (2011). Long-term impact of parental divorce on intimate relationship quality in adulthood and the mediating role of psychosocial resources. Journal of Family Psychology, 25(4), 615.

Neergaard, H., \& Thrane, C. (2011). The Nordic welfare model: Barrier or facilitator of women's entrepreneurship in Denmark? International Journal of Gender and Entrepreneurship, 3(2), 88-104.

Nilsson, P. (2015). The influence of urban and natural amenities on second home prices. Journal of Housing and the Built Environment, 30(3), 427-450.

North, D. C. (1990). Institutions, institutional change and economic performance. Cambridge: Cambridge University press.

Noseleit, F. (2014). Female self-employment and children. Small Business Economics, 43(3), 549-569.

Patnaik, A. (2015). Reserving time for daddy: The short and longrun consequences of fathers' quotas. Cornell University, Ithaca, NY. http://ssrn.com/abstract, 2475970.

Rabe-Hesketh, S., \& Skrondal, A. (2008). Multilevel and longitudinal modeling using Stata. STATA press.

Richomme-Huet, K., Vial, V., \& d'Andria, A. (2013). Mumpreneurship: A new concept for an old phenomenon? International Journal of Entrepreneurship and Small Business, 19(2), 251-275.

Roberts, P. W., \& Greenwood, R. (1997). Integrating transaction cost and institutional theories: Toward a constrainedefficiency framework for understanding organizational design adoption. Academy of Management Review, 22(2), 346373.

Royston, P., \& Lambert, P. C. (2011). Flexible parametric survival analysis using Stata: Beyond the cox model.

SCB. (2018). Women and men in Sweden. Facts and figures, 2018.

Schultz, T. P. (1990). Women's changing participation in the labor force: A world perspective. Economic Development and Cultural Change, 38(3), 457-488.

Skolnick, A. (2009). Grounds for marriage: How relationships succeed or fail. Family in transition, 192-201.

Sundström, M., \& Duvander, A. Z. E. (2002). Gender division of childcare and the sharing of parental leave among new parents in Sweden. European Sociological Review, 18(4), 433447.

Svanlund, J. (2011). I skuggan av den svenska modellen.

Thébaud, S. (2010). Masculinity, bargaining, and breadwinning: Understanding men's housework in the cultural context of paid work. Gender \& Society, 24(3), 330-354.

Thébaud, S. (2015). Business as plan B: Institutional foundations of gender inequality in entrepreneurship across 24 industrialized countries. Administrative Science Quarterly, 60(4), 671-711.

Thébaud, S., \& Pedulla, D. S. (2016). Masculinity and the stalled revolution: How gender ideologies and norms shape young Men's responses to work-family policies. Gender \& Society, 30(4), 590-617. 
Ucbasaran, D., Lockett, A., Wright, M., \& Westhead, P. (2003). Entrepreneurial founder teams: Factors associated with member entry and exit. Entrepreneurship Theory and Practice, $28(2), 107-128$.

Welter, F. (2011). Contextualizing entrepreneurship - Conceptual challenges and ways forward. Entrepreneurship Theory and Practice, 35(1), 165-184.

Welter, F., Brush, C., \& De Bruin, A. (2014). The gendering of entrepreneurship context. Bonn Institut für Mittelstandsforschung Working Paper, 1/14.

Wennberg, K., Wiklund, J., Hellerstedt, K., \& Nordqvist, M. (2011). Implications of intra-family and external ownership transfer of family firms: Short-term and long-term performance differences. Strategic Entrepreneurship Journal, 5(4), 352-372.
Westlund, H. (2011). Multidimensional entrepreneurship: Theoretical considerations and Swedish empirics. Regional Science Policy \& Practice, 3(3), 199-218.

Westlund, H., Larsson, J. P., \& Olsson, A. R. (2014). Start-ups and local entrepreneurial social capital in the municipalities of Sweden. Regional Studies, 48(6), 974-994.

Wiklund, J., Nordqvist, M., Hellerstedt, K., \& Bird, M. (2013). Internal versus external ownership transition in family firms: An embeddedness perspective. Entrepreneurship Theory and Practice, 37(6), 1319-1340.

Wooldridge, J. (2002). Introductory econometrics analysis of cross section and panel data. Cambridge: The MIT Press.

Publisher's note Springer Nature remains neutral with regard to jurisdictional claims in published maps and institutional affiliations. 